\title{
Dimensions Of Islamic Education In The Prevention Bullying; Assessing In An Effort Of Character Building For Children In School
}

\author{
Qolbi Khoiri \\ Program Studi PAI Pascasarjana IAIN Bengkulu \\ qolbikhoiri@gmail.com
}

\begin{abstract}
Bullies assume that violence and intimidation are compatible to be applied as the problem solving to achive they wish. This encourages violence properties that will carry over into adulthood. Thus unwittingly making school or other educational institution as a training ground for potential thugs who would later become their profession adulthood. Widely accepted definition is that a state that the student is doing the bullying when a child repeatedly and at all times behave negatively to one or more other children. Here is a negative action when someone intentionally hurt or try to hurt, or make someone uncomfortable. The point is not directly implied in the definition of aggressive behavior. This can affect the character of the child to grow up, the character is moral and mental qualities that formation is influenced by congenital factors (natural) and environment (socialization or Education - nurture). Islam provides a potential explanation that has good character of human beings before birth, but this potential must be constantly nurtured through socialization and Islamic religious education in schools, while Islamic religious education should be done in a planned, systematic and measurable in order to prevent and deal with bullying behavior child.
\end{abstract}

\section{Keywords: Bullying, Character Building, Islamic Religious Education}

\section{INTRODUCTION}

Education is a conscious and deliberate effort to create an atmosphere of learning process for children to actively develop the potential for them to have the spiritual strength of religious, self-control, personality, intelligence, noble character, and the skills needed themselves and society. But without realizing many cases of violence both within school postscript sublime place or other places. Imagine, almost every day, there's always news about violence among students. Start of fights, theft, and sexual abuse, to drug consumption. In fact, the violence committed by female students in several schools in Indonesia, has opened the eyes of all people, how violence among students were increasingly worried. Recent cases of violence against children rampant. Form of threats or bullying is more frequent in some form such as for food, asked for duties until the test when asked to be given a cheat sheet. Another case is a mockery to his friends until a friend who mocked crying. There was also a habit to call her by the name of their father or not the actual name of the student with the intent of harassing. A writer friend proudly tells his daughter that the new behavior of sitting in elementary school bullying to his friends with the tools to master the game during recess. An elementary school children proudly told his parents that he was very well known in his school because his friends feared. "I am who is chairman of the gang at school, " the boy said proudly.

Generally the parents, teachers and the community considers the phenomenon of bullying in schools is common and new respond if it has made to the injured victims in need of medical assistance in the event of physical bullying. While social bullying, verbal and electronic still not addressed properly. It is caused by a lack of understanding of the devastating impact of bullying on the development and achievement of children in school and not yet developed any mechanism or anti- bullying in schools. In addition the children are still rarely given an understanding of bullying and its effects. Children who are victims of bullying will suffer physically, depressed, cannot concentrate well at school or even withdraw from their social environment. Child who become victims of bullying will also be looking for an outlet that is negative like smoke, consume alcohol or even drugs. Due to prolonged stress can be disrupted health 
bullied. Even in the most extreme situations a victim of social bullying can commit suicide.

Bullies assume that violence and intimidation are compatible to be applied as the problem solving to achive they wish. This encourages violence properties that will carry over into adulthood. Thus unwittingly have made school a training ground for potential thugs who would later become their profession adulthood. Where children learn or inspired doing the bullying ? Children generally follow the behavior of the adults around them such as parents and teachers. How to educate children who tend to use violence at home and in school unknowingly teach children to do the same to his friends. Punishing children in ways that will teach children negative for other children as well as the power to justify acts of violence against other children who are weaker. Often due to limited knowledge and understanding of bullying has unwittingly encouraged the children doing the bullying at school or in the neighborhood?

\section{LITERATURE REVIEW}

Definition of bullying behavior is controversial and has not found a universally recognized definition, so there is no standard definition to date. Sejiwa (2008) said bullying comes from the English, the meaning of the word bull butting uncontroled. The term was eventually taken to describe a destructive action. In contrast to other countries, such as Norway, Finland, Denmark, and Finland which mentions the term mobbing or bullying mobbing? The term originates from the UK, the mob who stressed that the mob is a group of people usually are anonymous and are numerous and involved violence. While Schwartz et al (2005:2), refer to the term bullying victimization. Bush et al. add the term peer exclusion and victimization to describe bullying behavior. Tattum view that bullying is a desire to hurt and most have to involve an imbalance of power that a person or group who is a victim who does not have the power and the treatment was repeated and assaulted no Opinions expressed by the same relative. Sejiwa stating that bullying is a situation where someone is strong (physically and mentally able to) suppress, discredit, harass, hurt someone deliberately weak and repetitive, to show his power. In this case the victim was not able to defend or defend themselves because of weak physically or mentally (Sejiwa. 2005:1)

The important thing here is not just the actions taken, but what is the impact of such actions on the victim. For example, a student pushed his shoulder with a grunt ; when driven feel intimidated, especially when the action is done repeatedly, the bullying behavior has occurred. When students are encouraged not feel scared or intimidated, then the action cannot be said to be bullying. Bullying is also to be distinguished from other aggressive actions or behavior. Distinction is not to say if someone is bullying others jokingly flirt, fight that happened only once, and abusive acts or fights that are not aimed at causing destruction or damage both materially and mentally. In addition it cannot be said if the bullying including crimes such as assault with sharp weapons, physical violence, serious actions to harm or kill, serious theft, and sexual harassment are done only once.

Widely accepted definition is that states that the student is doing the bullying is when a child repeatedly and at all times behave negatively to one or more other children. Here is a negative action when someone intentionally hurt or try to hurt, or make someone uncomfortable. The point is not directly implied in the definition of aggressive behavior. Based on some understanding of bullying above, it can be concluded that bullying behavior is a negative action performed repeatedly where the act is done deliberately in order to hurt and make a person feel uncomfortable.

\section{Character Factors Affecting Children and Progress}

Character is defined differently by different parties. Most mention the character as a subjective assessment of the moral and mental qualities, while others say the character as a subjective assessment of the quality of mental alone, so that efforts to change or shape the character is only concerned with the intellectual stimulation of a person (http://encyclopedia.thefreedictionary.com).

Coon (1983:23), defines character as a subjective assessment of the person's personality is related to personality attributes that may or may not be accepted by society. Meanwhile, according to Megawangi (2003:12), the quality of the character includes nine pillars, namely ( 1 ) Love God and all His creation, (2 ) Responsibility, Discipline and Self, (3 ) honest / trustworthy and Arif, (4) Respect and Courtesy ; ( 5 ) Generous, Likes to help, and mutual - together ; ( 6 ) Confident, Creative and Hardworking ; ( 7 ) Leadership and fair ; ( 8 ) Good and humble ; (9) 
Tolerance, peace love and unity. So, according to Ratna Megawangi (2003), people who have good character is the character who has the ninth pillar.

Character, as well as other qualities, does not develop by itself. On each individual character development is influenced by congenital factors (nature) and environmental factors (nurture). According to developmental psychologist, Megawangi (2003) said every human being has the inherent potential to be manifested after he was born, including the potential associated with the character or virtues. In this regard, Confucius - a famous Chinese philosopher - basically states that humans have the potential love of virtue, but if this potential is not followed by education and socialization after humans are born, then people can turn into animals, even worse. Therefore, the socialization and education of children with regard to virtues - both in family, school, and the wider environment-is critical in shaping a child's character.

If socialization and education (nurture factor) is very important in character education, then since when should it be done ? According to Thomas Lichona (Megawangi: 2003), character education needs to be done at an early age. Erik Erikson -who is famous for the theory Psychosocial Development- also said the same thing. In this case Erikson says that the child is the image of early man became men, the period in which the virtues of growing slowly but surely. In other words, when virtue fails basics instilled in children at an early age, then he will become an adult who does not have good values . Furthermore, White, stated that the first two years of life are a critical time for the formation of patterns of personal and social adjustment (Hurlock. 1981: $80)$.

Exposure can be concluded that the character of a person's mental and moral qualities which formation is influenced by congenital factors ( nature - nature) and environment ( socialization or Education nurture ). Potential good character of human beings before birth, but this potential must be constantly nurtured through socialization and education from an early age.

\section{Bulling Behavior Prevention Strategies for Children}

So what must be done to reduce or even eliminate bullying in schools? First, in the school environment should be built awareness and understanding of bullying and its impact on all stakeholders in the school, ranging from students, teachers, principals, school officials to parents. Socialization of anti-bullying programs need to be done in stages so that all stakeholders understand what it is bullying and its effects. Then the system or mechanism should be constructed to prevent and deal with cases of bullying in schools. In this stage need to be developed school rules or codes of conduct that supports the school a safe school environment and comfortable for all children and reduce the occurrence of bullying as well as bullying victims handling systems at each school. This system will accommodate how a child who is being bullied to report the events that happened without fear or shame, and redress for victims of bullying, etc.

Equally important is to stop the violent practices in school and at home that contribute to bullying as a child-friendly education pattern with the application of positive discipline at home and at school. This step requires a strong commitment from teachers and parents to stop harmful practices in educating children. Training on positive methods of discipline needs to be done to teachers and parents in this stage. Last is to build the capacity of children in terms of protecting him from bullies and not be a perpetrator. For the children can be included in the anti- bullying training and actively participated in the campaign against bullying in schools. In this stage the method from child to child ( child to child) can be applied in campaigns and training.

Then what about the role of government? It is time for the government to give attention to the issue of bullying in schools and seeks to build the capacity of its institutions in addressing this issue. Strategic steps to be taken is to put this issue in teacher training materials and developing anti bullying program at each school. In some cases bullying can come into contact with the legal aspects, the law enforcement officers involved in the anti- bullying program will be very effective. School as an institution in charge of educating the nation is supposed to be a safe, comfortable and dignified for our children so they can grow and develop optimally. Thus, we have to prepare the next generation of superior and ready to become good citizens. So far, several attempts have been made by the school for bullying perpetrators, namely punishing sanctions and calls the parents to the school to work together to provide treatment. The results achieved so far is not maximized, because, 
according to the writer's observation, changes in attitudes and bullying behavior is only temporary. Since they returned to repeat his actions the other day. To help the handling of the bullying problem the author tried to offer the concept of behavioral counseling. By Gerald Corey that : "behavioral therapy ( counseling behavior) is the application of a variety of techniques and procedures that are rooted in theories of learning. Meanwhile, according to Kramboltz and Khoresen the quotation by $\mathrm{H}$. Moch Surya that "behavior therapy is a process of helping people to learn to solve interpersonal problems, emotional and particular interests". The emphasis in this sense the term learning is the notion that counselors help people (counselee) learning or changing behavior. Counselor's role to help in the learning process of creating the conditions is such that the client can change its behavior and solve the problem. The use of behavioral counseling as an alternative to solving the problem, according to the authors for considering behavioral counseling has basic concepts as follows :

1. Humans are reactive creatures whose behavior is controlled by external factors. Humans begin life by reacting to their environment and these interactions generate behavioral patterns which then form a personality.

2. A person's behavior is determined by a lot and stuff reinforcement received in her life situation.

3. Learned behavior when individuals interact with the environment through the laws of learning (classical habituation, habituation operand and impersonation)

4. Certain behaviors in individuals affected by satisfaction and dissatisfaction are obtained.

5. Humans are not the result of unconscious impulse but rather the result of learning, so that it can be changed by manipulating and create the conditions forming behavior.

By looking at the above advantages of behavioral counseling, the authors hope to minimize bullying in school institutions, so that the school can be a safe place to learn, fun, stimulating a desire to learn, socialize and develop all potential students both academically, socially and emotionally. In addition, the behavior Noting community, including teenagers and children, who are very concerned about this now, this condition, one of them, implies the need for an overhaul in the way of character education approaches and fundamentally. Character education in ways that have been done, both at home and at school, seems to have been powerless to shield children from the negative influences of life is contagious in the current era of globalization and decentralization today.

Home and school need to rearrangement- way character education has been implemented in a manner that is more appropriate, in addition they also need to complete it in ways other approaches and more thoroughly. In more operational, school and home finally recommended to perform the following remediation efforts in character education.

With all the existing limitations, every home needs to seek the creation of a living laboratory that allows children to grow and the formation of a good character. Parents need to enhance their knowledge and educational way so as to create a higher quality education interaction with his son. At home there needs to be structure and rules of humane behavior, clear, and enforced by every member of the family. Even the parents are required to play a role as a model in applying these rules. The schools that have a more limited approach of Explicit Teaching Character and Values in education need to improve the implementation of the approach, rather than adding new lessons, in addition to equip it with other approaches are more appropriate. Where possible, and why not, the school can apply Smorgasbord and holistic approach to the role of schools ( as well as home ) as a living laboratory that facilitates the formation of the character of the child are met.

Smorgasbord approach to character education is done by building a community of caring (caring community). Everyone in the school -students, teachers, and other staffadministration treats everyone else well and respect. In order to meet such a lofty goal, students need to play an active role in building a culture and environment in the classroom and school wide. To create such an atmosphere can be done by organizing meetings that conditioned class student groups formulate goals, make decisions based on rules of behavior, plan activities, and solve problems ; condition the students collaborate on academic tasks by working in groups cooperative learning ; giving them opportunities to plan and reflect on the ways they work together ; Organizing a program that allows children of different ages to work together on academic tasks and the types of activities; Teach conflict 
resolution and skill other social - skills so that children become skilled at solving conflicts fairly and peacefully. Above ways to help children learn to build and maintain positive relationships with others, while also conditioning the school into a living laboratory that conditioned the children to practice different types of roles and overcome the challenges they will face in the next life.

School and home should not run alone, much less conflicting. They need to be in a synergy through communication and collaboration are harmonious. Schools need to design programs that invite and condition parents are actively involved in supporting school programs. Schools also need to conduct consulting services that can improve knowledge and insight to rearrangement parental education and treatment. Conversely, parents also need to support school programs, in addition to providing feedback - feedback for program improvement school.

\section{DISCUSSION}

Islam is really paying attention to akhlak (Islamic Ethich) coaching aspect, it can be seen from the gesture of Al - Quran which states that the Prophet Muhammad had great morals : wainnaka la' ala khuluqin azim (Surat al - Qalam : 4). Finer Prophet exemplified them, to maintain trust, trustworthy, socialize and communicate effectively with appropriate human dignity, helping a fellow human being in his favor, glorify guests, avoid arguments, understand the values and norms, maintain the balance of the ecosystem, as well as consulted in affairs for the common good. The presence of the Prophet as the messenger of Allah to mankind at its core can be seen from his remarks : "Verily I (Muhammad) was sent into the world merely to enhance human morality" (al Hadith).

Islam also gives a very clear picture, the fact that the human aspect of creation has a very important role for better decission beings and nature (al-baqarah : 30) and functions related to self better decission (Adh-Dzariat: 56). In the two verses confirm that man was created as a pioneer for the entire contents better decission despite their natural tendency to corrupt, and humans have a primary duty as a servant of any command of Allah. Therefore, the steady pace in response to the call of Islam and the steadfast heart in implementing what has been the duty and obligation, then he will be able to capture signals that lie behind his worship. Because, in every service that is required by Islam contains philosophical values, such as the philosophical values that exist in the prayers, ie as 'aun (aid) for people in the seas of life (al-Baqarah: 153), and as a solid fortress to avoid, blocking, and anticipating the waves abomination and munkar (al-Ankabuut: 45).

The general objective of Islamic education is to achieve a quality that is mentioned by the Qur'an and hadith, while the function of national education is to develop the skills and character development and civilization of the nation's dignity in the context of the intellectual life of the nation, aims to develop the potential of students to become human faith and fear of God Almighty, noble, healthy, knowledgeable, skilled, creative, independent, and become citizens of a democratic and accountable. To carry out the functions of the government held a national education system listed in Law No. basis. 20, 2003. According Zuhairini means " efforts in a systematic and pragmatic in helping the students in order for them to live according to the teachings of Islam" (McDevitt. Et.all. 2002:199)

Furthermore, education experts have tried understanding Islamic education, among a very varied restrictions are (Zuhairini . 1983: 27):

1. Al-Syaibany suggested that Islamic religious education is the process of changing individual behavior of students in private life, society and the natural surroundings. The process is carried out by means of education and teaching as something human activities and professions among the many human professions in society.

2. Muhammad Fadhil al- slam Jamaly defines education as an effort to develop, encourage and invite students to live more dynamically based on the values of the high and noble life. With these processes, expected to form a more personalized those perfect learners, whether in relation to the potential intellect, feeling and acts.

3. Ahmad D. Marimba argued that Islamic education is a conscious guidance or leadership by educators for physical and spiritual development of the students towards the formation of the main personality ( perfect man )

4. Tafseer Ahmad Islam defines education as the guidance given by a person that he 
develop optimally in accordance with the teachings of Islam. Some can be understood that the above understanding of Islamic religious education is an activity, a process, a conscious effort, planned, systematic and measurable in the context of the formation of students' character in accordance with the main mission of the Islamic Shari'a.

With this definition, it appears the real Islam gives a very deep attention to the moral formation of students akhlak oriented (Islamic Ethic) commendable perfection as desired in the Law System of Education No. 20 of 2003 which includes ; faith and fear of God Almighty, noble, healthy, knowledgeable, skilled, creative, independent, and become citizens of a democratic and accountable. All components of the national education goals above, it should be an aim of Islamic education outlined in the main mission of the creation of man, therefore, the Islamic religious education also gave considerable attention to bullying behavior in school-aged children.

Islam asserts that the behavior bullying which includes a negative acts carried out repeatedly that the act intentionally committed with intent to injure and make someone feel uncomfortable, is a commendable act, so that any such action should be avoided.

In order to avoid those actions are not praiseworthy at the bullying behavior, Islamic Religious Education has provided guidance prevention and mitigation. The main principles of prevention and management philosophy is seen in the task of educators and learners in Islamic education. Muhammad Zuhaili in Ahmad Tafsir (2005: 45) said outlines that the educator is a cornerstone of education and teaching mission, he was the first vehicle to realize the goals and principles of education. educators is the source of the first broadcasters to help learners of despicable deeds and dark spaces of life in order to achieve a happier life.

Abdurrahman An-Nahlawi stated that the educator is a person who serves as a selfcleaning, self-maintainer, developer and maintainer of human soul, educators also are those who do the transfer of knowledge to all the people that can be used in everyday life (Zuhaili: 2002). From the definition above can be understood that the educator is the one who did the educational process and are responsible for the students, both physically and spiritually. In the context of Islamic education, educators are the most responsible for the success of the education is aspired in accordance with the spirit of Islam (An-nahlawi. 1995:169-170)

While learners are closely related to the basic concepts of the man himself, so talk about humans that also means learners discuss the basic concepts that always needs help in living life in order to achieve a decent life, and in accordance with the rules set by the creator. Therefore the basic concepts of human in Islam, Hamka (1982: 172) stated in His word in surah Al - Baqarah verse 30, which means :

و إذ قال ربك للملا ئكة إنى جاعل فى الأرض خليفة ( البقرة : (30)

" And remember when your Lord said to the angels: ' Look, I want to create khlaifah on earth " $Q S: 2 ; 30$ )

On the other verse Allah says that man is a slave created solely to worship Him (Hamka. 1982:37), as in the letters Az - Zariat which means:

$$
\begin{aligned}
& \text { وما خلقت الجن و الإنس إلا ليعبدون ( الذارية : 56 ) } \\
& \text { "I had not made the jinn and }
\end{aligned}
$$

humans except to serve (worship) me" ( $Q S$; Az-Zariat ; 56)

Regarding the process of the creation of man, al - quran is clear that human -created from a drop emitted, more details can be seen from the word of God ( Surah : $86: 5-6$ ). Syaid Qutb said citing the opinion that the reference to 'play dafiq ' is a blend of water emitted from the coccyx (spine) of men and women's water sternum ( bone top ). The secret of creation then becomes a separate science for humans in the middle ages (Ramayulis. 1998:51).

Then described in another letter about the creation process :

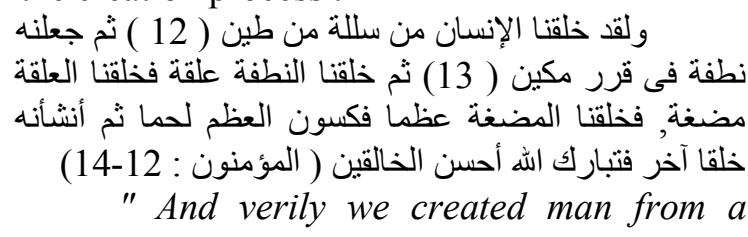
quintessence (derived) from the ground, then we make the quintessence of semen and stored in a sturdy (womb), then we make the semen blood clot, and the clot we made a lump meat, and a lump of flesh bones that we make, then we wrap the bones with flesh. Then we made it in the form of another creature. It be to almighty God the creator of the most good" ( Qur'an : 23 : 12-14)

This verse delivers on creating the perfect man, partly argued, this process lasted for 9 months 10 days in the mother's womb (Hamka. 1982:17-19), who then gods perfect creation spirit blowing through the bodies that had been shaped into the (Qur'an : 34:9). The 
verses about the creation of man above, actually has consequences that must be carried by humans for what has been created in God have the responsibility to be accountable before Him in the Hereafter. Therefore man is demanded to proceed towards a better, even though the real men are given the potential good and bad. The main task is to recognize the existence of his God and bear witness that Muhammad is His messenger. Given the sheer human need not testify but also need to know what is created by God, then humans are required to constantly seek knowledge, thus expected to achieve the purpose of creation is true, as stated in surah Al - Baqarah verse 30, and Adz - Dzariat paragraph 56 above.

Humans as gods creation is fundamental responsibilities totality of life, which is why, when asked later in accountability, then he is not entitled to impose guilt and blame to others. Therefore, this is where the role of education directing, guiding and giving explanations to humans in order to gain knowledge and way of life. In Islam, educators must know the needs and potential of what needs to be developed in a self-learners, so that someday they can live their rights and responsibilities as a servant of God and as a vicegerent on earth, while leaning on the al-Quran and al-Hadith. Departing from the above two concepts, the Islamic religious education should be able to prevent the child's behavior in school bullying with reference to the concept of systematic coaching.

Muhaimin Abdullah Amin (2003:312) claim that there are three stages of the process of religious education (including moral aqidah) that should be owned and experienced by the students along with the teachers, the first (cognition) is a transfer or provide religious knowledge as much as possible to the students, so the this activity aspects of cognition are dominant. The second stage, (affection), in addition to meeting the expectations in the first stage, the process of internalization of religious values is also expected to occur. The affective aspect of the rule is closely related to aspects of cognition. In the affective aspects of religious education should take precedence over the first aspects (cognition). In the third stage, (psychomotor) emphasizes the ability of the students to be able to motivate yourself, so it can move, run and obey basic values intenalized religion in itself through the second stage.

Implementation of moral education in religious education and cognitive development approach is needed, including the development of critical reasoning or process of engagement of students actively sense the first stage (cognition), which at the same time, followed by the second stage (affection) the rules of which are closely related to the first stage (cognition) and stages of activities (psychomotor). (Muhaimin. 2003:313)

For example, in the teaching of social ethics in its Al-Maun, it would be better if in addition to teaching about the verses should not rebuke orphans (cognition), children are invited to see the direct object clause, the orphans and the poor. For example, children are invited to orphanages and nursing homes, street children, victims of displacement to dialogue with them. So that children get salutation directly to the material being taught, so that foster social ethics. Some teachers attempt to integrate the values of moral education to the students, especially the students' efforts to shape the personality has to do with two kinds.

First, the teacher's role forms tend to like students who are (a) sets a great example, as well-dressed, disciplined, good personality, and is always giving advice to students, wise and prudent, (b) as a priest in prayers, (c) provide seven -minute lecture ( i.e Kultum) after prayer and recitation routinely conducted in schools, (d) provide motivation to learn in order to achieve good performance, (e) being a mentor discussion hosted by the student or the student council, (f) to be the coach advisory committees or in commemoration of the days of Islam, boarding lightning, and social activities organized by the school. While the role of the teacher who is not liked by the students are (a) teachers who have overbearing nature, (b) teachers who are often angry without cause, (c) teachers who do their job less discipline, (d) teachers who are less active support extracurricular activities.

Nevertheless the success of students in school moral education in general is influenced by several factors, both internal factors (factors that exist in the learner) and external factors (factors that are beyond the learners). Guru is one of the factors that contributed to the success of a student's education that includes cognitive, affective, and psychomotor. Likewise with the moral education of students, that teachers have a very important role participating students affect the formation noble character. Exemplary qualities, teacher discipline, and commitment in carrying out his duties as teacher educators will be used as an 
example by the students, and it is very influential on changes in student behavior in real life every day.

\section{CONCLUSION}

Bullying behavior is a negative action performed repeatedly xwhere the action deliberately undertaken with the aim to hurt and make a person feel uncomfortable. To help the handling of the problem of bullying seems to behavioral counseling concepts can be used as one way, this concept describes the behavioral therapy (counseling behavior) where the application of a variety of techniques and procedures that are rooted in theories of learning.

Behavior therapy is a process of helping people to learn to solve interpersonal problems, emotional and particular interests ". The emphasis in this sense the term learning is the notion that counselors help people (counselee) learning or changing behavior. Counselor's role to help in the learning process of creating the conditions is such that the client can change its behavior and solve the problem.

Islamic education should give special attention to the establishment of child mentality bullying behavior can be avoided so as early as possible to maximize the role and function of educators in instilling noble values in students who performed in a planned, systematic and measurable.

\section{REFERENCE}

An-Nahlawi, Abdurrahman. 1995. Ushuluttarbiyah wa-Asalibuha fi al-Baiti wa al-Madrasti wa Al-Mujtama', (translated) Sihabuddin, Pendidikan Islam di Rumah, Sekolah dan Masyarakat, Jakarta: Gema Insani Press

Coon, Dennis. 1983. Introduction to Psychology : Exploration and Aplication. West Publishing Co.

Hamka. 1982. Tafsir Al-Azhar, Jakarsta: Pustaka Panji Mas

http://encyclopedia.thefreedictionary.com. Diakses tanggal 26 April 2011.

Hurlock, E.B. 1981. Child Development. Sixth Edition. McGraw Hill Kogakusha International Student

McDevitt,. T.M. \& Ormrod, J.E. 2002. Child Development and Education. (Upper Saddle River, N.J.: Merill Prentice Hall

Megawangi, Ratna. 2003. Pendidikan Karakter untuk Membangun Masyarakat Madani, IPPK Indonesia Heritage Foundation
Muhaimin. 2003. Wacana Pengembangan Pendidikan Islam.Surabaya: Pusat Studi Agama, Politik dan Masyarakat-PSAPM

Ramayulis. 1998. Ilmu Pendidikan Islam,Jakarta: Kalam Mulia, 1998), printed, 2

Schwartz, D.dkk. 2005 Victimization in the Peer Group and Children's Academic Functioning., Journal of Educational Psychology

Sejiwa. 2008. Bullying, Mengatasi Kekerasan di Sekolah dan Lingkungan Sekitar Anak, Jakarta : Grasindo,

Tafsir, Ahmad. 2005 Ilmu Pendidikan Dalam Persfektif Islam, Bandung : PT. Remaja Rosdakarya

Zuhaerini. 1983. Metodik Khusus Pendidikan Agama. Surabaya : Usaha Nasional

Zuhaili, Muhammad. 2002. Al-Islam wa asSyabab, (ter) Arum Titisari, Pentingnya Pendidikan Islam Sejak Dini, Jakarta: Ba'adillah Press 